Anna Szafarczyk ${ }^{1}$

ORCID: 0000-0001-6130-2529

Andrzej Skaba ${ }^{2}$

ORCID: 0000-0002-5741-3899

Krzysztof Sokalla ${ }^{2}$

ORCID: 0000-0003-0076-0846

\title{
IMPLEMENTATION OF GYROSCOPE MEASUREMENTS IN UNDERGROUND MINES; FOCUS ON THE MINE OF RUCH (UNIT) „BORYNIA” IN THE JASTRZĘBIE COAL COMPANY
}

\author{
${ }^{1}$ AGH University of Science and Technology \\ ${ }^{2}$ JSW S.A. Ruch Borynia
}

Keywords: gyrotheodolite, gyroscopic measurement, basic orientation line

\begin{abstract}
Making excavations in underground mining enterprises is carried out in a strict co-operation of miners and mine surveyors. Carrying out exploitation in horizontal and vertical direction is based on the application of the control line, the accuracy characteristics of which is defined by legal regulations. Fulfilling accuracy requirement referring to the error of the point situation and the error of the line azimuth is often impossible without the application of gyroscopes. The implementation of gyroscope measurements in an underground mine is, first of all, connected with: better adjustment to the regulations referring to making measurements in mine excavations, especially in one-sided sequences, gyroscope measurements on the existing lines on the surface and in excavations, making the orientation of the excavations, constructing new levels in mines or new mines. The process of the implementation of gyroscope measurements was divided into several stages, i.e.: the development of the basic orientation line on the surface of the Ruch „Borynia” with newly stabilized points, on which a static GPS measurement, referring to the reference stations of grid ASG-EUPOS, carrying out the transformations of the co-ordinates of system 2000 to mine system SG-ROW and calculation of the azimuth of the lines in a local geodetic system, carrying out gyroscope measurements on several lines of the base on the surface in Ruch „Borynia”, determining gyroscope azimuths in mining excavations. The article also presents the results of first measurements made in mine excavations i.e. in one survey in Ruch „Zofiówka” and two surveys in Ruch „Borynia”, where in the distance of about $3.5 \mathrm{~km}$, between the lines of gyro, the measurement was carried out with the method of transect sequence with the method of three tripods. In the final conclusions of the article the conclusions of first experience of gyroscope measurements by the surveying department of Ruch „Borynia” JSW S.A. and initial assessment of the accuracy of gyrotheodolite Sokkia GYRO X1 II are made.
\end{abstract}

\section{WDROŻENIE POMIARÓW GIROSKOPOWYCH W KOPALNI PODZIEMNEJ NA PRZYKLADZIE RUCHU „BORYNIA” W JASTRZĘBSKIEJ SPÓLCE WĘGLOWEJ}

Słowa kluczowe: giroteodolit, pomiar giroskopowy, baza giro

\section{Abstrakt}

Drążenie wyrobisk w podziemnych zakładach górniczych realizowane jest przy ścisłej współpracy górników oraz mierniczych górniczych. Prowadzenie wyrobisk w określonym kierunku poziomym i pionowym bazuje na wykorzystaniu osnowy, 
której charakterystyka dokładnościowa określona jest obowiązującymi przepisami. Spełnienie wymagań dokładnościowych dotyczących błędu położenia punktu oraz błędu azymutu boku niejednokrotnie nie jest możliwe bez wykorzystania przyrządów giroskopowych. Wdrożenie pomiarów giroskopowych w podziemnym zakładzie górniczym uwarunkowane jest, przede wszystkim: lepszym dostosowaniem się do obowiązujących przepisów dotyczących wykonywania pomiarów w wyrobiskach górniczych, szczególnie w ciągach jednostronnie nawiązanych, odtworzeniem pomiarów giroskopowych na istniejących bokach na powierzchni i wyrobiskach udostępniających, wykonywaniem orientacji wyrobisk przy budowie nowych poziomów wydobywczych lub nowych kopalń. Proces wdrażania pomiarów giroskopowych został podzielony na kilka etapów, tj.: rozbudowę bazy giro na powierzchni Ruchu „Borynia” o nowo zastabilizowane punkty, na których wykonano pomiar statyczny GPS w dowiązaniu do stacji referencyjnych sieci ASG-EUPOS, wykonanie transformacji współrzędnych z układu 2000 do układu kopalnianego SG-ROW i obliczenie azymutu boków w lokalnym układzie geodezyjnym, przeprowadzenie pomiarów giroskopowych na kilku bokach bazy na powierzchni w Ruchu „Borynia”, wyznaczenie azymutów giroskopowych w wyrobiskach górniczych. W artykule przedstawiono również wyniki uzyskane z pierwszych pomiarów wykonanych w wyrobiskach górniczych, tj. z jednego pomiaru w Ruchu „Zofiówka” oraz dwóch pomiarów w Ruchu „Borynia”, gdzie przy odległości ok. 3,5 km pomiędzy bokami giro dokonano pomiaru ciągu poligonowego metodą trzech statywów. W podsumowaniu artykułu zawarto wnioski z pierwszych doświadczeń z pomiarów giroskopowych wykonywanych przez dział mierniczy Ruchu „Borynia” JSW S.A. oraz przeprowadzono wstępną ocenę dokładności giroteodolitu Sokkia GYRO X1 II.

\section{INTRODUCTION}

The regulations (Rozporządzenie..., 2015) about the accuracy measurements in underground geodetic control lines are considerably strict. Constructing new exploitation levels or mines, making excavations in the areas situated far away from the shafts requires making orientation to preserve proper accuracy of azimuths. Disambiguation of the control line, especially basic and detail, must be based on detail orientation of excavation towards the control line on the surface. For this purpose, the most often applied method of getting the best result is gyroscopic measurement (Grobler, 2015; Zhen et al., 2013). Gyroscope measurements, the purpose of which is to determine the topographic azimuth, allow detail control of the existing - often not up-dated underground control line, as well as develop the network to further regions based on the requirements indicated in the regulations.

Jastrzębska Spółka Węglowa (the Jastrzębie Coal Company) has been following the technological progress in the production of geodetic instruments for a long time. In recent years surveying departments bought many new devices: manual and stationary laser scanners, GPS receivers, electronic total stations, including motorial ones, precise code levellers. In 2018, it was also decided to buy a very specialist instrument - such as gyrotheodolite. Due to large costs of the purchase, rare use of this instrument, the only item was bought in the Hard Coal Mine „Borynia-Zofiówka-Jastrzębie” Ruch Borynia, with the idea to be applied in all the mining enterprises within JSW S.A.

\section{PREMISES AND IMPLEMENTATION OF THE PURCHASE OF THE GYROTHEODOLITE}

The main criterion of the purchase of the gyrotheodolite was the accuracy of marking the azimuth, automation of the measurement, availability and the quality of the product, as well as the price of the purchase. There are four producers of the instruments on the Polish market: the whole sets and individual attachments of gyroscopes constructed to apply in subsequent models of electronic total stations. As a result of market survey for the tender - the following offers were obtained:

- attachment GYROMAX AK-2M produced by GeoMess Technik Heger, Neubranderburg, Germant producer, characterised by the accuracy of marking the geographical azimuth $<60^{\mathrm{cc}}(20$ "),

- gyroscope station by Sokkia - Japanese production consisting of the total station by Sokkia model SX1 with gyroscope attachment GYRO X1 II and the accuracy of geographical azimuth equalling $45^{\mathrm{cc}}\left(15^{\prime \prime}\right)$,

- gyroscope station GIROMAT 3000 produced by DMT Essen Niemcy of the accuracy $10^{\text {cc }}(3$ ”),

- gyroscope station NTS-342G, Chinese production providing accuracy of the determination of geographic azimuth of about $45^{\mathrm{cc}}\left(15^{\prime \prime}\right)$.

As a result of the analysis of all the offers and based on experience of PGG S.A. KWK „Piast-Ziemowit” Ruch Ziemowit in Lędziny, the decision was made to buy the Japanese set of company Sokkia (photo 1) in 
December 2018. The decision was mainly caused by very good results obtained in Ruch Ziemowit, with very intensive clumping of excavations, the possibility of automation of the measurement and the price-quality ratio. The gyrotheodolite was bought with full equipment i.e. 5 heavy tripods with double security measures, 2 Freiberger plummets, 4 sets of mirrors, tribrachs and adapters by the Japanese company Topcon.

\section{MODIFICATION OF THE BASIC ORIENTATION LINE IN RUCH „BORYNIA"}

PMG Katowice on the turn of 2006 and 2007 stabilized the points of the basic orientation line on the surface of the mines of „Zofiówka” and „Borynia” to carry out the orientation of subsequent levels with the gyroscope method to connect the excavations of these mines. For the first time the determination of co-ordinates of these points with GPS in ASG-PL grid (Tarnowskie Góry, Katowice, Wodzisław, Żywiec) and grid POLREF (Radostowice) were carried out, indirectly obtaining the topographic azimuth of the base line on the surface, which was again determined by the gyroscope method towards the astronomic base in Sucha Gora (the beginning of the system of co-ordinates). In the mine of „Borynia”, the difference of determining GPS and gyroscope measurements $\Delta \mathrm{Az}=41^{\mathrm{cc}}$ were found, while in the mine of "Zofiówka” $\Delta \mathrm{Az}=80^{\mathrm{cc}}$ (PMG...2007). In 2019 the surveying section of Ruch „Borynia”, after buying the gyrotheodolite started the analysis of the usefulness of the base in their mine. It was decided that the base requires the modification meaning the elongation of the lines of the control line and the possibilities of the stabilization of the points, on which the horizon for the GPS measurements would be maximally uncovered. The network consisting of two new points G1, G2 and the existing base PMG i.e., G961, G962 was formed. On the turn of February and March 2019 the stabilization of points G1 and G2 was made by putting into concrete thick metal rods into the depth of about $90 \mathrm{~cm}$. This way a network of points of satisfactorily long lines of the control line was formed: line G1-G2 429.5m, line G1-G962 159.0 m, line G2-G962 270.6 m and the existing line of the basic orientation network PMG G961-G962 106.6m was created (fig. 1).

The following stage of the surveying was to make the primary angular-linear measurement of the base to

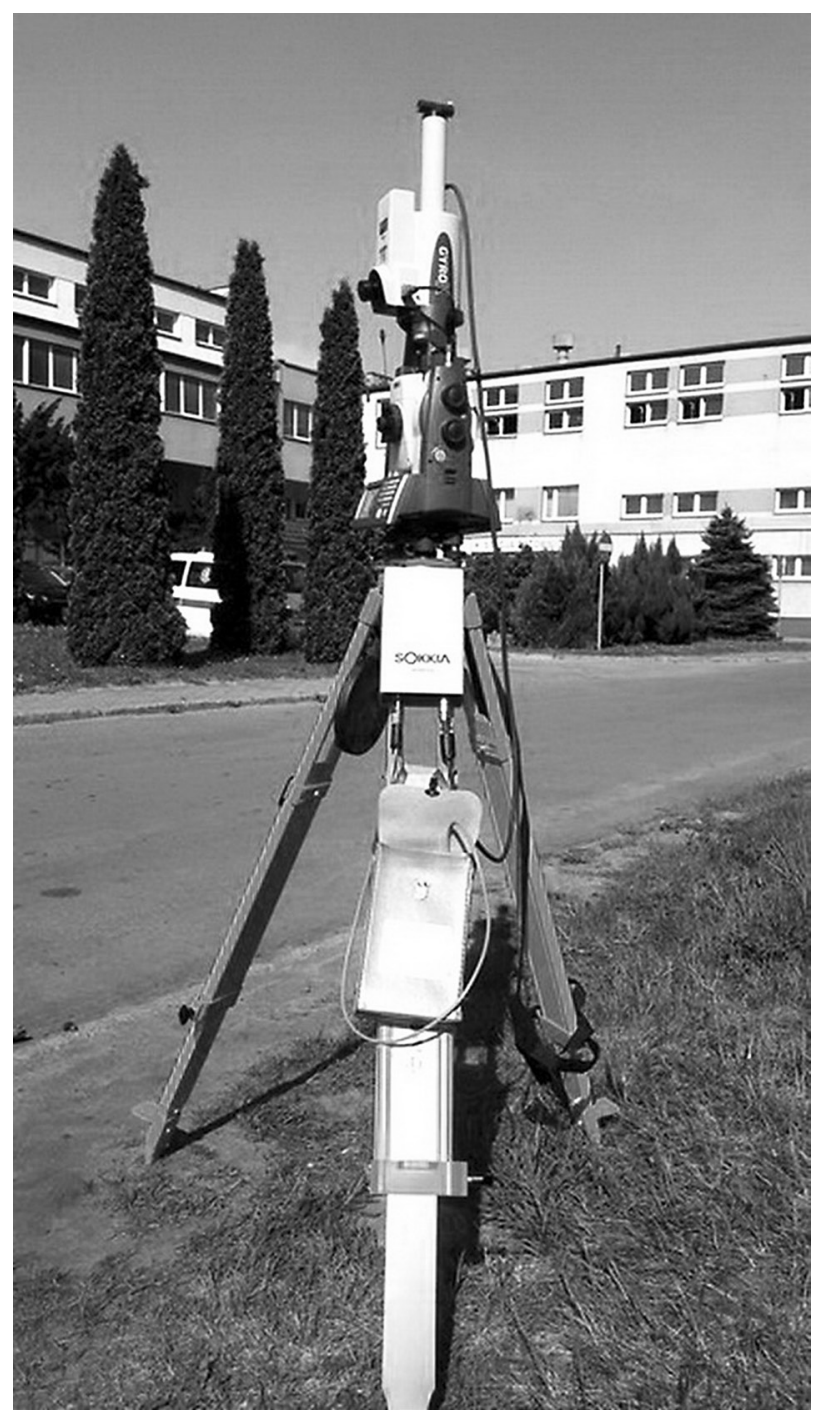

Photo. 1. The set of Sokkia gyroscope in Ruch „Borynia” Fot. 1. Zestaw giroskopowy firmy Sokkia w Ruchu „Borynia”

connect the existing control line i.e., lines G961-G962 with new points G1 and G2. A total robotic station of the gyro-set i.e., Sokkia SX series 1" was applied. Horizontal angles and lengths in triangle G1-G2-G962 and combination of lines G1-G962 and G962-G961 were measured. As a control the angles in the formed triangle G1-G2-G962 were summed up, obtaining the deviation from the theoretical value $4^{\mathrm{cc}}$, which can be recognized as a very good result, compliant with the class of the surveying instrument. Then the static GPS measurement with the application of three receivers of Trimble (model R4-II, R8-II, R10) put at the same time on points G1, G2 and G962 in the time of $2 \mathrm{~h}$ and 30 minutes. The 


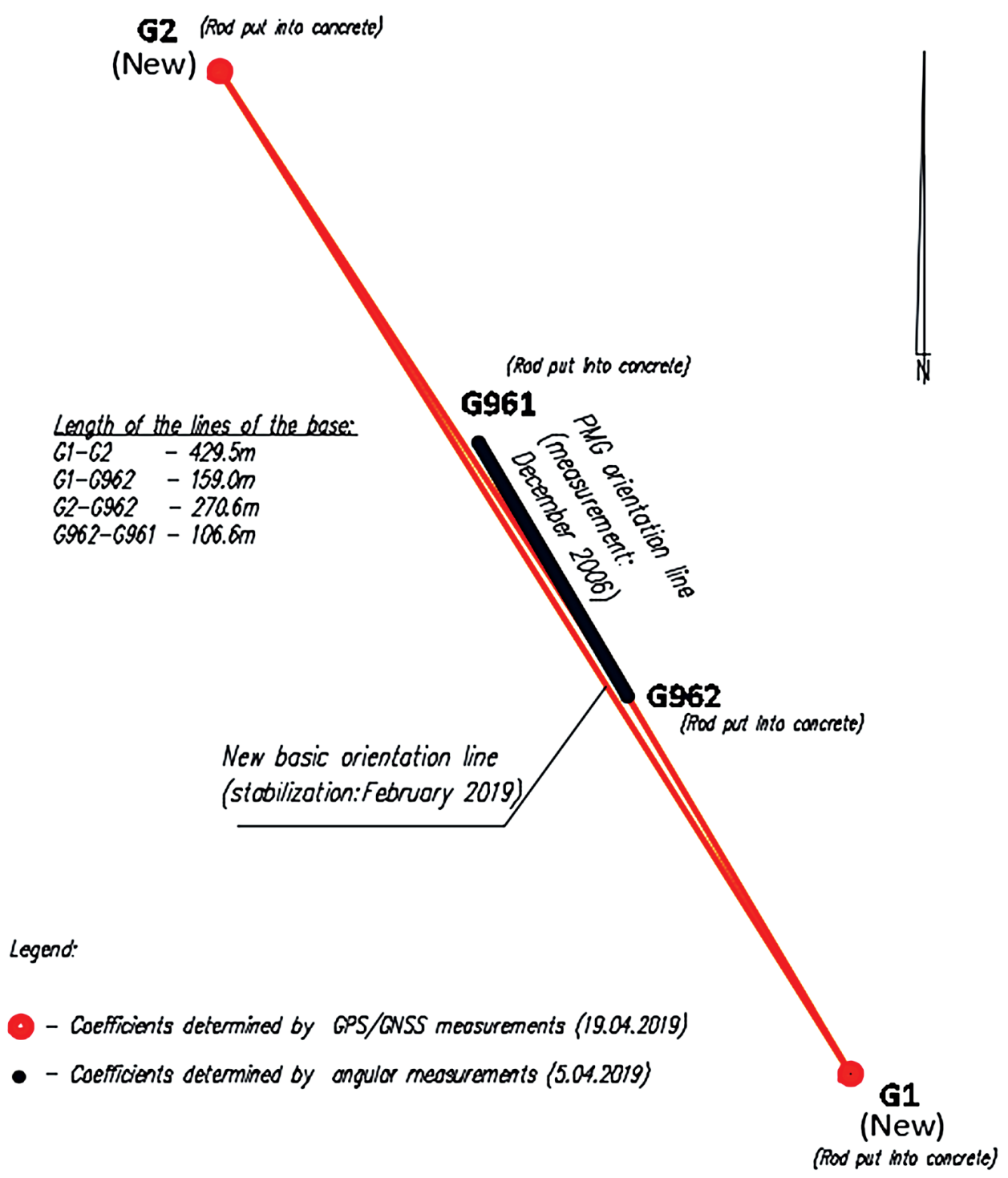

Fig. 1. The sketch of basic orientation line modernized in 2019 in Ruch „Borynia”

Rys. 1. Szkic zmodernizowanej bazy giro w 2019 r. w Ruchu „Borynia”

process of levelling was carried out in software TBC (Trimble Business Center). In the first tests of calculations the conclusion was made that point G962 has bigger errors of marking co-ordinates, on the contrary to points G1 and G2. Probably it was the result of the close vicinity of the tower of shaft $\mathrm{I}$, forming the north line and the building of the pithead from the south. Thus it was decided that in the GPS network only two points, i.e., G1 and G2, without G962 will be formed. Such a reference system control line for the basic orientation line allowed obtaining the most accurate topographic azimuth, due to a large distance between these points, are $429.5 \mathrm{~m}$. The coordinates of points in system 2000 and the azimuth of line G1-G2 are presented in table 1. The azimuth was calculated according to literature (Szafarczyk et al., 2017).

As a result of levelling of the static GPS measurements of points $\mathrm{G} 1$ and $\mathrm{G} 2$, flat coordinates in system 2000 were obtained. Mines JSW in the area of Jastrzębie-Zdrój and Pawłowice have the local system of Sucha Gorra-ROW (SG-ROW). Considering the above, the coordinates of the mentioned above points were transformed from system 2000 into system SG-ROW, indirectly by system 1965 . 
Table 1. Record sheet of GPS static measurement on the basic orientation points in 2000 reference system

Tabela 1. Zestawienie wyników z pomiaru statycznego GPS punktów bazy w układzie 2000

\begin{tabular}{|c|c|c|c|c|c|c|}
\hline $\begin{array}{c}\text { Point } \\
\text { No. }\end{array}$ & $\mathbf{X}[\mathbf{m}]$ & $\mathbf{Y}[\mathbf{m}]$ & $\mathbf{m}_{\mathbf{X}}[\mathbf{m}]$ & $\mathbf{m}_{\mathbf{Y}}[\mathbf{m}]$ & $\begin{array}{c}\mathbf{A z}_{\mathbf{G 1}-\mathrm{G} 2} \\
{[\mathbf{g r a d}]}\end{array}$ & $\mathbf{M}_{\mathrm{AZG1}-\mathrm{G} 2}[\mathbf{c c}]$ \\
\cline { 1 - 4 } G1 & 5540425,225 & 6543949,103 & \pm 0.005 & \pm 0.004 & 363.8296 & \pm 13 \\
\cline { 1 - 4 } G2 & 5540787,227 & 6543718,008 & \pm 0.004 & \pm 0.003 & & \\
\hline
\end{tabular}

Based on the carried out static GPS measurements and angular-linear measurements, strict levelling of the modernized basic orientation line started. As reference points coordinates of points G1 and G2 in system SGROW were accepted with the errors of components $m_{x}$, $\mathrm{m}_{\mathrm{y}}$ at the level $\pm 8 \mathrm{~mm}$. Errors of angular observation were assumed based on technical data of the robotic total station Sokkia SX series 1" i.e., $M \alpha= \pm 3^{\mathrm{cc}}$. Errors of length were also weighted based on the instruction data of the instrument.

The idea of the levelling of the horizontal network was to include the calculation of topographic azimuths in system SG-ROW for new lines as well as the existing line 961-962 (base PMG), to compare them. The arising system of observation equations had 4 supernumerary observations at the measurements of 4 horizontal angles, 4 lengths, 2 reference points (points G1 and G2) and 2 levelled points (G962, G961). In the process of strict levelling an individual error of the levelling of network $\mathrm{M}_{0}=0.98$, which proves that the observations were correctly weighted. The errors of $\mathrm{mx}$, my achieved values around $\pm 6 \mathrm{~mm}$, but for the basic orientation line the most important were the values of levelled topographic azimuths and their errors, which are presented below in table 2 .

Levelled azimuths in system SG-ROW will be applied in the calculation of the topographic corrections with the use of the calculations of topographic azimuths taking part in the process of the orientation of excavations with the gyroscope method. One should add that, in the strict levelling, also the azimuth of the base line of the existing basic orientation line was calculated, i.e., 961-962. As a result of comparing its value with the measurement PMG of 2006 and the measurement JSW of 2019 , the deviation of $124^{\mathrm{CC}}$ was obtained.

\section{IMPLEMENTATION OF GYROSCOPE MEASUREMENTS JSW S.A.}

After the purchase of the equipment the phase of practical tests of the instrument to choose the best measurement method. According to the instruction (Instrukcja..., 2011) the gyroscope set Sokkia can determine the direction of the north with the time method (so-called period of oscillations) or the method of the turning points, preserving the same accuracy of the measurement. For practical reasons, the measurement was made only with the turning points method.

After carrying out the modernization of the basic orientation line in Ruch „Borynia” and referring the points of the control line base to the state system of co-ordinates with the application of static GPS measurements first gyroscope measurements towards this base were carried out. First practical measurements included the measurement basic orientation line on the surface of Ruch „Zofiówka” and marking the azimuth

Table 2. Record of aligned topographic azimuth values (SG-ROW reference system) on basic orientation line with errors Tabela 2. Zestawienie wyrównanych wartości azymutów topograficznych (układ SG-ROW) bazy giro wraz z błędami

\begin{tabular}{|c|c|c|c|}
\hline No. & Line & $\begin{array}{c}\text { Topographic azimuth } \\
\text { (system SG-ROW) [grad] }\end{array}$ & $\begin{array}{c}\text { Mean error of the azimuth } \\
\text { after levelling } \mathbf{M}_{\text {Az }}[\mathbf{c c}]\end{array}$ \\
\hline 1 & G962-G1 & 166.3025 & 16.5 \\
\hline 2 & G1-G2 & 364.5771 & 16.4 \\
\hline 3 & G962-G2 & 363.5636 & 16.4 \\
\hline 4 & G962-G961 & 366.6600 & 16.7 \\
\hline
\end{tabular}




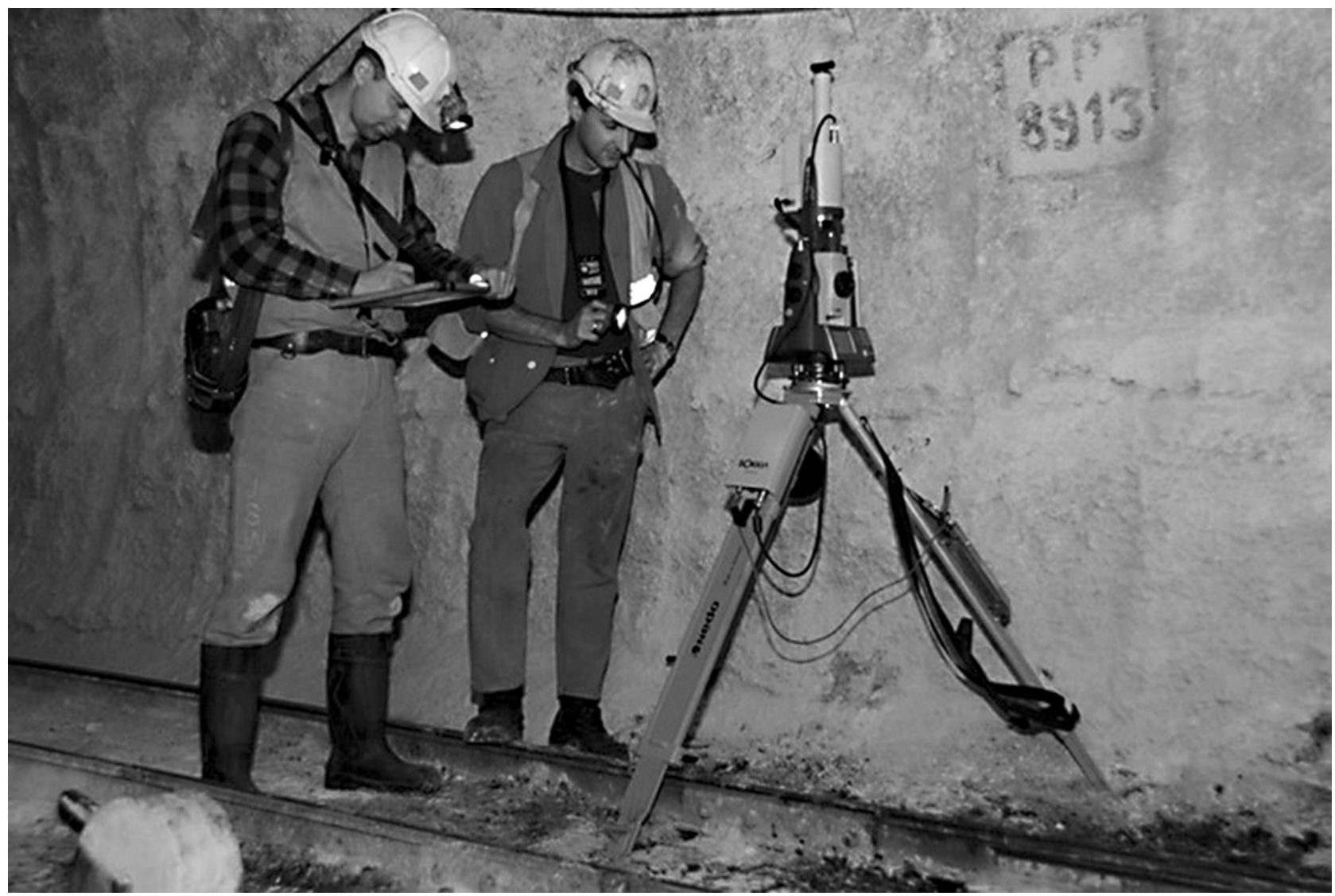

Photo 2. The survey of gyroscopic azimuth in the dike directional S on level 838 in Ruch „Borynia”

Fot. 2. Pomiar azymutu giroskopowego w przekopie kierunkowym S na poz. 838 w Ruchu „Borynia”.

in the excavation, i.e., in the gallery at the wall B-3a in seam 407/1 in Ruch „Zofiówka” (June, 2019).

The following measurements were carried out in August 2019 in Ruch „Borynia” i.e., gyroscopic measurement of two lines in directional piercing $\mathrm{S}$ on level 838 and in piercing $\mathrm{W}$ on level 838 to modernize the horizontal control line (photo 2). In Ruch Borynia, it is planned to carry out the measurement of about 5 gyro-azimuths on level 950 and connect them through polygonisation with level 838 , obtaining a uniform network of the horizontal control line. One should notice that at the first stage of these works also connections through polygonisation between two gyro lines on level 838 , in the distance of $3.5 \mathrm{~km}$.

Azimuths of the lines of the reference of the measured sequence (4916-4917 and 8075-8913) were calculated based on the results of gyroscope measurement, regarding a topographic correction determined on base line G962-G1 on the surface, and corrections for the convergence of meridians. There were 18 angles and 19 lengths measured in a sequence. Horizontal angles were measured in two series with closing the horizon and the lengths twice from both lines with the use of total station SX1 being an integral part of the gyrotheodolite GYRO X1 II. As a result of levelling the sequence an angular deviation was obtained equalling $10^{\mathrm{CC}}$, which indicates high accuracy of the measurement of horizontal angles (mean error of the angle was $\pm 4^{\mathrm{CC}}$ ). Making the values of azimuths calculated from gyroscope measurements, independent from errors of horizontal angles made on earlier checkpoints of the sequence causes that gyroscope measurements can be applied to increase the accuracy characteristics of the whole mine network. As it has already been mentioned, in the near future it is planned to carry out such measurements and again equalise subsequent fragments of the mine detail control line. More supernumerary observations in the process of the levelling of the whole network will strengthen it. 


\section{ACCURACY ANALYSIS OF GYROSCOPE MEASUREMENTS}

In assessing the accuracy of gyroscope measurements, one should consider two issues: the accuracy of determining the base localized on the surface of the area, meant to determine topographic correction and accuracy of gyroscope azimuth measured on the base line and on the points of the mine control line localized in underground mining excavations.

\subsection{The accuracy of determining the azimuth of the base line}

Measurements carried out on the base line, used in determining co-ordinate points making base, should be made with highest possible accuracy.

To achieve this, GPS technology was applied in the static mode, supplemented with angular-linear measurements, (fig. 1) obtaining mean situation error of points $\mathrm{G} 1$ and $\mathrm{G} 2$ equalling \pm 5 and $\pm 4 \mathrm{~mm}$, respectively. At the base length G1-G2 equalling $429.5 \mathrm{~m}$, the mean error of topographic azimuth calculated from these co-ordinates was $\pm 13^{\mathrm{CC}}$. The value of this error should be the smallest possible, because the topographic azimuth determined on the base line is considered the pattern and it is used to determine the topographic correction.

The accuracy of the topographic azimuth of the base line was controlled also by carrying out the measurement in the triangle made on base points $\mathrm{G} 1$ and $\mathrm{G} 2$ and point G962. Results of angular-linear measurements carried out on the lines of this triangle, together with the jointly made measurement GPS in a static mode were strictly levelled, and coordinates determined this way were applied to calculate the values of topographic azimuths in the SG-ROW system (table 2). The values of topographic azimuths in the SG-ROW system were also determined based on the carried out measurement of gyroscope azimuth from two lines, independently, of all the three check points of the analysed triangle and accepting, as the baseline G962-G1 (table 3).

As a result of the comparison of these values, for lines G1-G2 and G962-G2 the obtained differences between the values of topographic azimuths determined with two independent methods were $+5^{\mathrm{CC}}$ and $-14^{\mathrm{CC}}$, respectively. The discrepancy of this kind shows high accuracy of the determined topographic azimuth of the base, high precision of the measurements and equipment, as well as care about the correct way of carrying out all the elementary procedures being able to assess the result of the measurement.

\subsection{Accuracy of the measurement of the gyroazimuth}

The accuracy of the measurements of the azimuths of a gyroscope depends on the applied measurement methods, as well as the field conditions.

In case of the applied gyrotheodolite, among the available methods, the „Follow" method was chosen, i.e., return points (Instrukcja..., 2011) and two measurements from each of two ends of the line, choosing the longest possible line. A particular attention was paid on the accuracy of centering the instrument and signals, because the participation of this error in the azimuth error is significant (Szafarczyk et al., 2017).

Due to the fact that the measurement of gyroscope azimuth is carried out twice, from two ends of the measured line, the results of such measurement make the pairs of spots. The carried out assessment of the accuracy of many equally accurate spots allowed the

Table 3. Comparison of topographic azimuths from exact alignment basic orientation line and independent determination of azimuth in gyroscopic method according to line G962-G1

Tabela 3. Porównanie azymutów topograficznych z wyrównania ścisłego bazy i niezależnego wyznaczenia azymutu metodą giroskopową względem boku G962-G1

\begin{tabular}{|c|c|c|c|}
\hline Line & $\begin{array}{c}\text { Topographic azimuth } \\
\text { from strict levelling (SG-ROW) } \\
\text { [grad] }\end{array}$ & $\begin{array}{c}\text { Topographic azimuth determined } \\
\text { from gyroazimuth (SG-ROW) } \\
\text { [grad] }\end{array}$ & $\begin{array}{c}\Delta \mathrm{Az} \\
\text { [cc] }\end{array}$ \\
\hline G1-G2 & 166.3025 & 166.3020 & 5 \\
\hline G962-G2 & 363.5636 & 363.5650 & -14 \\
\hline
\end{tabular}


definition: the error of mean individual measurement and the mean error of the arithmetic mean of two measurements, equalling: $\pm 18^{\mathrm{CC}}$ and $\pm 14^{\mathrm{CC}}$, respectively, at the mean error of singular measurement declared by the producer equalling $\pm 45^{\mathrm{CC}}$ (Instrukcja..., 2011). The above values were defined based on the analysis of seven measured gyroazimuths determined in different field conditions (on 6 lines of the underground control line in the mine and on the base line on the surface).

\section{CONCLUSIONS}

The purchase of gyroscope equipment at the end of 2018 was caused by the need for gyroscope measurements by all the mining enterprises belonging to JSW S.A. and the possibility to increase the level of measurement technologies in the surveying sections. Very expensive equipment was bought, which will be used for many years while building new exploitation levels or mines, building shaft vents, orientation of the existing excavations and in distant mining excavations, for which control measurement is necessary to keep the accuracy of the azimuths of the control line and to fulfil the regulations (Rozporządzenie..., 2015). First practical experience and the obtained measurement results turned out to be very promising both in the Ruch "Zofiówka" and Ruch "Borynia". In the following months this equipment will be applied also in other mining enterprises, where it will not be necessary to carry out time consuming tender procedures. The purchase of this type of equipment by JSW S.A. gives the possibility to have such specialist services carried out more often in surveying sections, which allows mine surveyor to design the control line more safely at very large mine front runway, if necessary. The presented arguments fully justify the decision to buy a gyrotheodolite of a Japanese company Sokkia.

\section{ACKNOWLEDGEMENT}

The publication is financed by the funds of the Department of Mine Areas Protection, Geoinformatics and Mine Surveying no. 16.16.150. 545

\section{REFERENCES}

Instrukcja obsługi GYRO X firmy Sokkia, Tokio 2011.

$P M G$ Katowice: Realizacja osnowy poziomej i wysokościowej dla połączenia wyrobisk górniczych Kopalń Jastrzębskiej Spółki Węglowej S.A. KWK Zofiówka i KWK Borynia. Katowice 2007.

ROZPORZĄDZENIE MINISTRA ŚRODOWISKA z dnia 28 października 2015 r. w sprawie dokumentacji mierniczogeologicznej (Dz.U. z 2015 r. poz. 1941).

Szafarczyk A., Młynarczyk. J., Markiewicz Ł., Gawałkiewicz R. (2017). Design, measurement and analysis of gyro-azimuths influence on the results of aligning the underground control network. Geoinformatica Polonica, 16, 77-86.

Grobler H. (2015, April 24). Spatial positioning of Sidewall stations in a narrow tunnel environment. A safe alternative to traditional mine survey practice. $\mathrm{PhD}$ thesis. Johannesburg: University of the Witwatersrand.

Zhen S., Zhiqiang Y., Zhang Z. (2013). Study on automatic north-seeking key technologies of Maglev gyroscope. The Open Mechanical Engineering Journal, 83-89. 